\title{
ATP bioluminescence - for kitchen hygiene and cleaning control of surgical instruments
}

\author{
D. Hansen, M. Hilgenhöner, W. Popp \\ University Hospital Essen, Germany \\ doi:10.3396/ijic.V4i1.010.08
}

\section{Introduction}

Success of cleaning has to be verified in reprocessing of medical devices. Visual assessment has limitations, therefore reprocessing procedures are often monitored by microbial cultures or determination of residual blood or protein on real instruments after reprocessing.

All these methods have considerable disadvantages:

- Results of microbial methods are not available at once.

- Some pathogenic bacteria require specific growth conditions or a long cultivation period and thus are missed on routine microbiological methods.

- Described methods for detection of residues of protein or blood are too cumbersome to be performed routinely at reprocessing sites for medical devices.

- Dosage of reagents of some commercially available assays has a risk to be imprecise because of improper equipment (Figure 1).

- Interpretation of results is subjective when, for example, residual protein is detected by a modified Biuret reaction and compared to a colour card (Figure 2).

Methods for quality control should be easy to perform and results should be available in time for corrective action to be taken at once. In our opinion,
ATP bioluminescence seems to be appropriate to verify success of cleaning in reprocessing of medical devices. ATP is a cellular constituent of all living cells and is present in bacteria and cells of animal or plant origin as well. Thus it is an indicator of organic as well as microbial contamination, with the exception of viruses and prions which do not contain ATP. Because viruses are intracellular parasites and require living cells to survive they may be detected indirectly by the presence of cells.

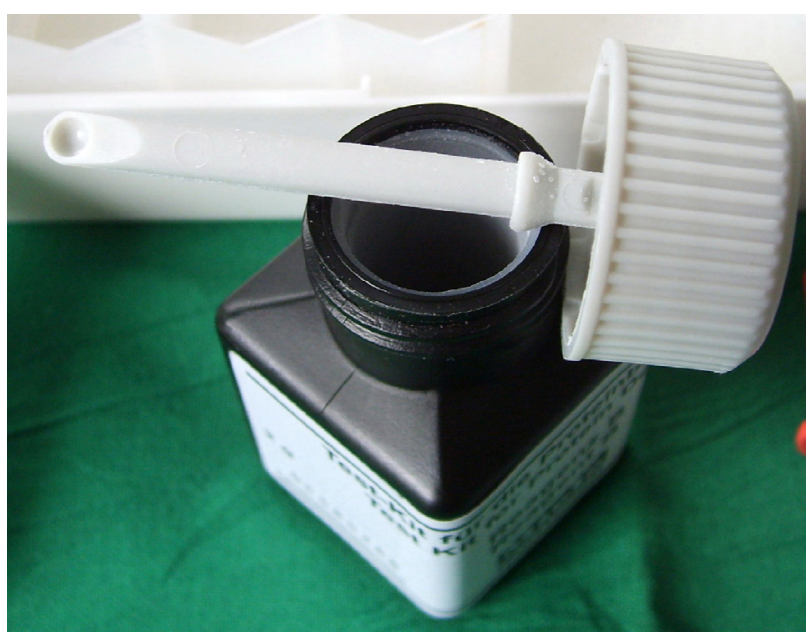

Figure 1. Small spoon for dosage of reagents of a commercially available protein assay

\section{Corresponding author}

D. Hansen, M, University Hospital Essen, Germany 


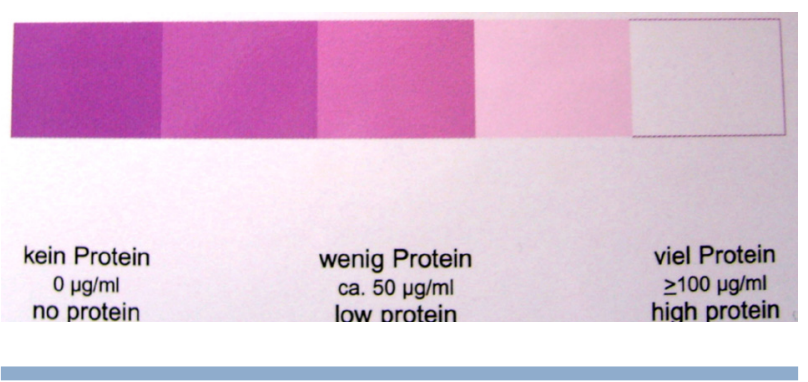

Figure 2. Example of a colour card for protein measurement in a modified Biuret assay

\section{ATP bioluminescence in general and in kitchen hygiene}

The method of ATP bioluminescence is derived from a reaction that occurs naturally in the firefly. ${ }^{1}$ Firefly luciferase catalyzes the production of light from luciferin in the presence of ATP, $\mathrm{Mg}^{2+}$ and molecular oxygen. ${ }^{2}$ The intensity of emitted light measured by the luminometer indicates the amount of extracted ATP and therefore organic contamination. ${ }^{3,4}$

The commercially available ATP bioluminescence assays are easy to perform and results are available within minutes. The ATP bioluminescence method was introduced in the 1960s and 1970s and has been tested in different applications., ${ }^{3,5}$ Only after introducing low cost portable luminometers and swabs already containing a special diluent for extraction of intracellular ATP (easily applied by non technical staff) the method became widely accepted to control surface cleanliness in food and kitchen hygiene in the 1990s. ${ }^{8,10-11}$ Application of ATP measurement for hygiene control in the food industry is endorsed by many studies. ${ }^{1,12-15}$

The speed of ATP bioluminescence assays makes them very useful for quality control of cleaning processes. However, target values and critical limits have to be assessed according to individual hygienic demands and experience. Microbial ATP concentration is dependant on metabolic activity, content of nutrient, $\mathrm{pH}$, temperature and supply of oxygen. ${ }^{4}$ The quality of the surface from which swabs are taken also influences the amount of extracted ATP. ${ }^{4}$ Some authors calibrated the light units they got by measuring serial dilutions of different bacteria in order to determine the detection limit of their method and to define critical limits. ${ }^{16}$

\section{ATP measurement in quality control of reprocessing of medical devices}

Although ATP measurement may be a suitable method to control the quality of reprocessing of medical equipment it has not been introduced into clinical routine. Few studies have compared ATP bioluminescence with microbiological cultures in detecting contamination after reprocessing of flexible endoscopes. ${ }^{16-18}$ They showed that bioluminescence is an adequate method to assess the efficacy of cleaning steps and should complement microbiological culturing.

In our hospital, ATP bioluminescence is used in addition to microbiological methods to check endoscope reprocessing. We decided on a threshold of $100 \mathrm{RLU}$ (relative light unit) for the Lumitester PD 10 (Scil Diagnostics) to be most suitable. Between November

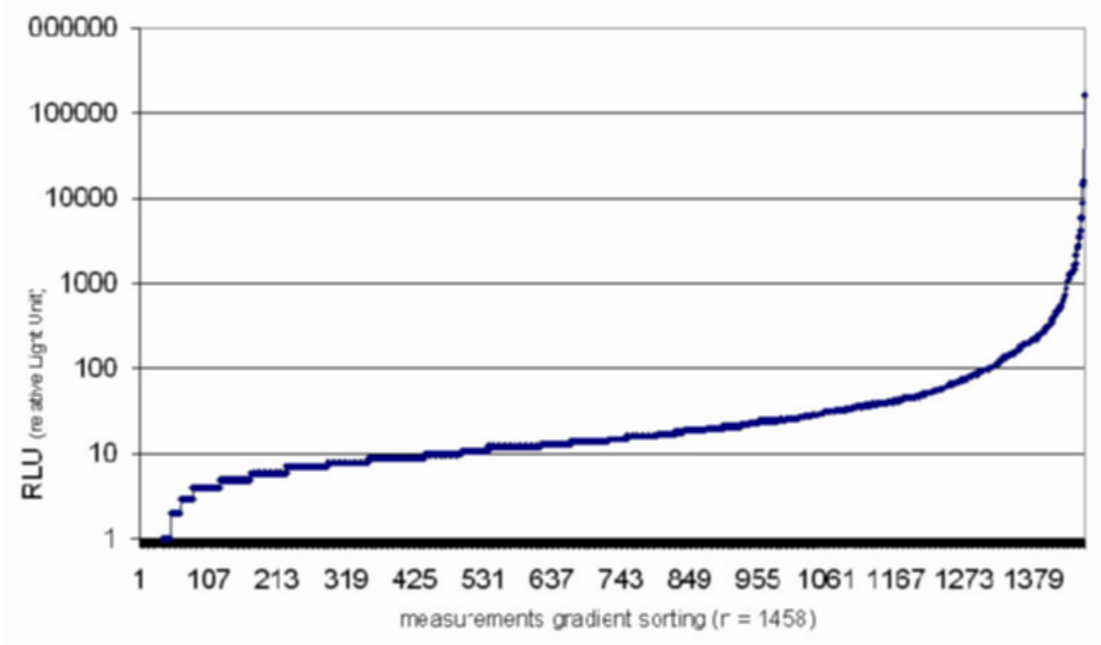

Figure 3. Results of determination of residual ATP of reprocessed endoscopes from November 2002 to February 2007 


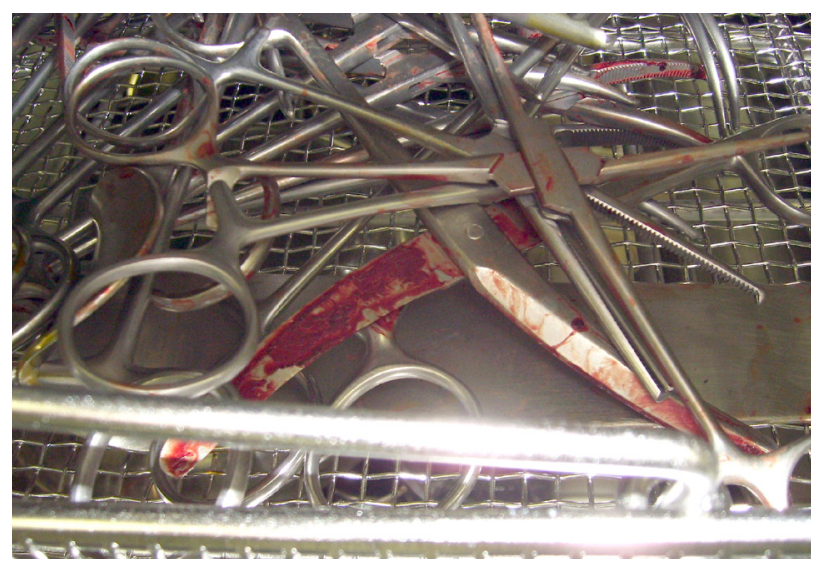

Figure 4. Example of real contaminated instruments before cleaning

2002 and February 2007 we performed 1458 ATP bioluminescence measurements of reprocessed flexible endoscopes. Results are shown in fig. 3. In 9.8 $\%$ of tests measured ATP bioluminescence was above the threshold of 100 RLU. Endoscopes with an ATP bioluminescence value above limit after reprocessing are reprocessed immediately.

Another application of ATP bioluminescence may be quality control of reprocessing of surgical instruments. Takashina and Slotsbjerg tested the ATP bioluminescence method to determine residual contamination on surgical instruments after cleaning and disinfection. ${ }^{19-20}$ Takashina even quantified residual ATP and therefore he was not only able to verify success of reprocessing of surgical instruments but also to compare different processes and chemical products. ${ }^{19}$

We use the ATP bioluminescence assay to verify the cleaning of real contaminated surgical instruments in the context of validation of washer-disinfectors (fig. 4). Threshold was defined as 100 RLU (relative light unit) according to that of reprocessed endoscopes. Our results of determination of residual ATP on surgical instruments after cleaning is shown in fig. 5 . In $6.4 \%$ measured ATP bioluminescence was above the threshold and lead to trouble-shooting of the cleaning process.

In our opinion determination of residual ATP is superior to determination of residual protein by a modified Biuret reaction: It takes only a few minutes and may be more sensitive. For example, a surgical instrument similar to those shown in fig. 4 visually appeared clean after reprocessing and no protein was measured by Biuret reaction. However the swab taken from its joint space showed a red discoloration and the residual ATP bioluminescence value was 267,977 RLU.

From our experience we conclude that determination of residual ATP on surgical instruments after washing is suitable for quality control of the cleaning process and should be applied more often.

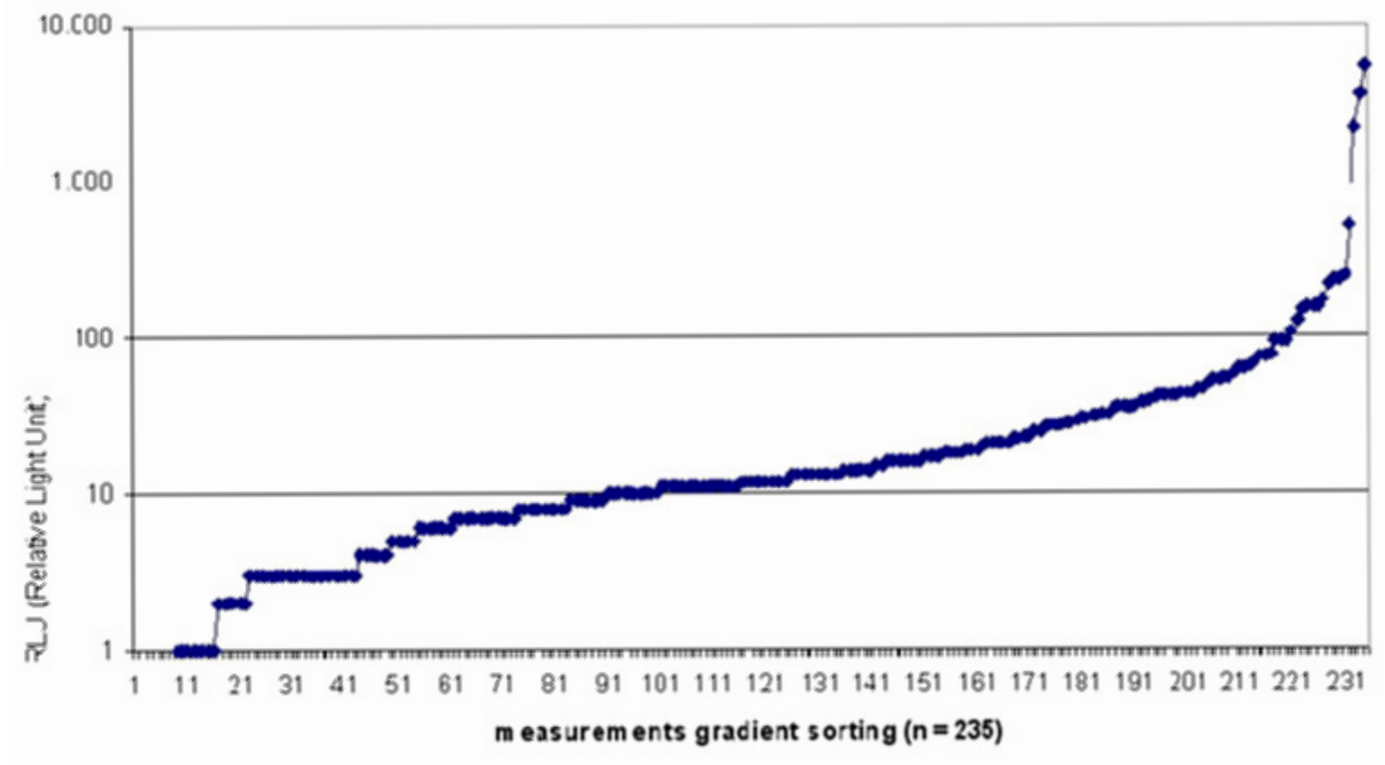

Figure 5. Results of determination of residual ATP of surgical instruments after cleaning from May 2005 to November 2007 


\section{References}

1. Aycicek H. Oguz U, Karci, K. Comparison of results of ATP bioluminescence and traditional hygiene swabbing methods for the determination of surface cleanliness at a hospital kitchen. Int J Hyg Environ Health 2006; 209: 203-206.

2. DeLuca M, McElroy WD. In DeLuca, M. (ed.), Methods in Enzymology. Academic Press, New York, 1978; 57: 3-15.

3. Prioli RP, Tanna A, Brown IN. Rapid methods for counting mycobacteria - comparison of methods for extraction of mycobacterial adenosine triphosphate (ATP) determinated by firefly luciferase assay. Tubercle 1985; 66: 99-108.

4. Baumgart ]. [Rapid methods of process control of cleaning and disinfection procedures - their benefits and their limitations.] Zbl Hyg 1996; 199: 366-375.

5. Ruokonen A, Koskinen M, Leinonen M, Tilikainen A, Vihko R. Screening of bacteria in urine using luciferin-luciferase assay of microbial ATP: a comparative study. Ann Clin Biochem 1982; 19: 416-420.

6. Webster JJ, Walker BG, Ford SR, Learch FR. Determination of sterilization effectiveness by measuring bacterial growth in a biological indicator through firefly luciferase determination of ATP. J Biolumin Chemilumin 1988; 2: 129-133.

7. Stanley PE. A review of bioluminescent ATP techniques in rapid microbiology. J Biolumin Chemilumin 1989; 4: 375380.

8. Griffith J, Blucher A, Fleri J, Fielding L. An evaluation of luminometry as a technique in food microbiology and a comparison of six commercially available luminometers. Food Science and Technology Today 1994; 8 (4): 209-216.

9. Sakakibara T, Murakami S, Kazuhiro I. Enumeration of bacterial cell numbers by amplified firefly luminescence without cultivation. Analytical Biochemistry 2003; 312: 48-56.

10. Seeger K, Griffiths M.W. Adenosine triphosphate bioluminescence for hygiene monitoring in health care institutions. J Food Prot 1994; 57 (6): 509-512.
11. Murphy SC, Kozlowski SM., Bandler DK. Boor KJ. Evaluation of adenosine triphosphate-bioluminescence hygiene monitoring for trouble-shooting fluid milk shelf-life problems. J Dairy Sci 1998; 81: 817-820.

12. Bautista DA, Mclntyre L, Laleye L, Griffiths MW. The application of ATP bioluminescence for the assessment of milk quality and factory hygiene. J Rapid Methods Automation Microbiol 1992; 1: 179-193.

13. Griffiths MW. The role of ATP bioluminescence in the food industry: new light on old problems. Food Technol 1996; 6: 62-72.

14. Hawronskyj JM, Holah J. ATP: a universal hygiene monitor. Trends Food Sci Technol 1997; 8: 79-84.

15. Ukuku DO, Sapers GM, Fett WF. ATP bioluminescence assay for estimation of microbial populations of fresh-cut melon. J Food Prot 2005; 68 (11): 2427-2432.

16. Sciortino CV, Xia EL, Mozee A. Assessment of a novel approach to evaluate the outcome of endoscope reprocessing. Infect Control Hosp Epidemiol 2004; 25: 284-290.

17. Hansen D, Benner D, Hilgenhöner M, Leisebein T, Brauksiepe A, Popp W. ATP measurement as method to monitor the quality of reprocessing flexible endoscopes. Germ Med Sc 2004; http://www.egms.de/ en/gms/2004-2/000014.shtml [Accessed September 15, 2008]

18. Obee PC, Griffith CJ, Cooper RA, Cooke RP, Bennion NE, Lewis $M$. Real-time monitoring in managing the decontamination of flexible gastrointestinal endoscopes. Am I Infect Control 2005; 33(4): 202-206.

19. Takashina M. Eine Biolumineszenzmethode zur Überprüfung des Reinigungsergebnisses. Zentr Steril 2001; 9 (4): 248-258.

20. Slotsbjerg, A. Residual ATP measuring is more suitable for evaluating cleaning results of surgical instruments than visual inspection and a residual protein test. Sixth International Conference of the Hospital Infection Society, Amsterdam 2006. 